\title{
Strategic Choices: The Case Of Management Accounting System
}

\author{
Muhammad H. AL-Hazmi, King Fahd University of Petroleum and Minerals, Saudi Arabia
}

\begin{abstract}
While the popularity of strategic management accounting (SMA) has been growing over the last decade, there is still not an extensive literature, which directly addresses the relationship between management accounting system and strategy. The Management Accounting Research (MAR) constructed a special issue on SMA and concluded that (1) there were less than 20 key articles on this subject in the mainstream academic journals; (2) there was a lack of comprehensive conceptual framework for SMA; and (3) there was limited empirical evidence. To explore this and related issues, a study of the relative significance of the use of cost information for strategic considerations in relation to two levels of competitive analysis -_corporate competitive intelligent information, and business competitive intelligent information - was undertaken. The findings of the study relate managers_ perceptions of two dimensions of their environmental changes (stability and certainty) to the two levels of competitive analysis. In order to gain a wider understanding of this relationship, a random sample of 110 large Saudi companies were selected and data collected from senior managers. The results showed that (1) the perceptions of managers differ between their environmental certainty and stability; (2) the relative significance accorded to business competitive intelligent information was positively associated with rising instability; (3) the use of corporate competitive intelligent information was a common practice. An interpretation of the results is that market instability stimulates strategic movement and cost information is being used in management thinking to support strategic development in meeting competitive pressures and in restructuring and reconfiguration of business strategy.
\end{abstract}

Keywords: Management Accounting; Cost Management; Strategic Management Accounting; Accounting Practices.

\section{INTRODUCTION}

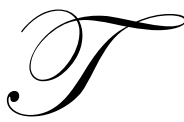

he importance of accounting information in strategy development and implemetation is well docmented in the literature (Simmonds, 1981; Shank, 1989, Shank and Govindarajan, 1989; Bromwich, 1990; Dent, 1990; Simons, 1990; Wilson, 1991; Mia and Clarke, 1999; Cooper and Slagmulder, 1998; Slagmulder, 1998; Keith and Roozen, 1999). These and other authors expressed concerns with traditional management accounting for its failure to link strategic choices of the firm.

Traditional Managemnt Accounting System (MAS) tends to rely on historical and financial internal information and ignores external factors related information. These external environmental factors may create a shift in the core competence and alter the long-term direction and the strategic choices of a firm, and subsequently, lead to adjust the performance targets and the search for better perfomance measures for internal use. This process is continuous and the MAS can provide a broader range of external information necessary to support strategy development and strategic change process.

While the recent development of balanced scorecard is used as a strategic implementation tool, the strategies are only evaluated at the beginning of a new planning cycle or whenever the firm repositions itself to cope with existing market turbulence. However, some questions concerning the use of MAS information in shaping strategic decision in the light of the changing environment is still unsolved. 
The literature on strategy and management accounting raises the question of how internal analysis and accounting process can help the management team to formulate and implement better strategies (Keith and Roozen, 1999; Kasurinen, 2002). The main objective of this study is to explore the link among external environment, use of information and strategic choices of a firm. In particular, the study relates managers' perceptions of two dimensions of their environment (certainty and stability) to their use of MAS information in shaping strategic choices at two levels of relative significance accorded to competittive intelligent information. Little attention was paid to this linkage in the literature.

\section{STRATEGY DEVELOPMENT AND MANAGEMENT}

\section{ACCOUNTING INFORMATION}

There is a considerable agreement in the literature on the scope of strategic choice which is believed to embrace: (1) corporate strategy that deals with the allocation of resources among various businesses or divisions of an enterprise; (2) business strategy that concerns primarily the question of competitive position of a particular business or division of an enterprise; and (3) functional (operational) strategy that is limited to specific areas (e.g., marketing and distribution) within a particular business (Hofer and Schendel, 1978; Dent 1990; Wilson 1991; Johnson and Scholes 1993).

Ansoff and Sullivan (1993) use a contingency model to optimize a firm's performance through strategic alignment with environmental changes. Keith and Roozen (1999) have developed a model to include the concept of environmental changes and differing information needs in terms of scope, structure and content. They have suggested a strategic accounting system that can provide managers with the type of strategic information they need.

Mia and Clarke (1999) have found out that the use of information increases with environmental changes and managers' use of information plays a mediating role in the relationship between the intensity of market competition and business unit performance. This result explains the problem with Khandwalla's findings where he has not found a significant relationship between the types of competition and organization profitability.

On the other hand, Quinn (1980), Harrison (1987) and Nixon and Alasadair (1992) have assumed that strategy could be used as "the intervening (mediator) variable between the organisation and the external environment". In relation to management accounting, it could be seen as "the means by which the firm decides to pursue opportunities in which it has a comparative advantage and takes corrective actions to compensate for those areas in which it has a comparative disadvantage" (Nixon and Alasadair1992, p 12). Hence, the relationship between organization performance and environmental changes will be explained by mediators which include both: (1) strategy as an external mediator which specify objectives and impose certain policies and, (2) managers' use of information provided by MAS as an internal mediator which identify the directions and creates certain practices. It is suggested that the relationship of strategy and MAS can be extended by relating both to perceptions of environment. Therefore, strategy is likely to be derived in relation to perceptions of the environment and that there would be a relationship between the relative significance of the uses of management accounting information and perceived environmental conditions of illiberality and unpredictability.

For strategy to work, it is essential to define (1) the specific information needed to facilitate the strategic process and (2) the criteria of workable strategy before reaching the end of the road. In this case, MAS can provide the range and the type of information needed by managers in relation to their strategic choices and the perception of the environment.

The scope of strategic choices includes three different levels of enterprises, namely: corporate, business and functional (figure 1). Each strategy is concerned with specific sets of strategic choices and alternatives and should be supported with the type of information they need. Since the information appears to be an important key to the process of strategic decision making, the process of gathering, processing and reporting information may be centralized in the accounting department (Keith and Roozen, 1999). 
Figure 1 : Environmental Changes, Strategy and Management Accounting Information

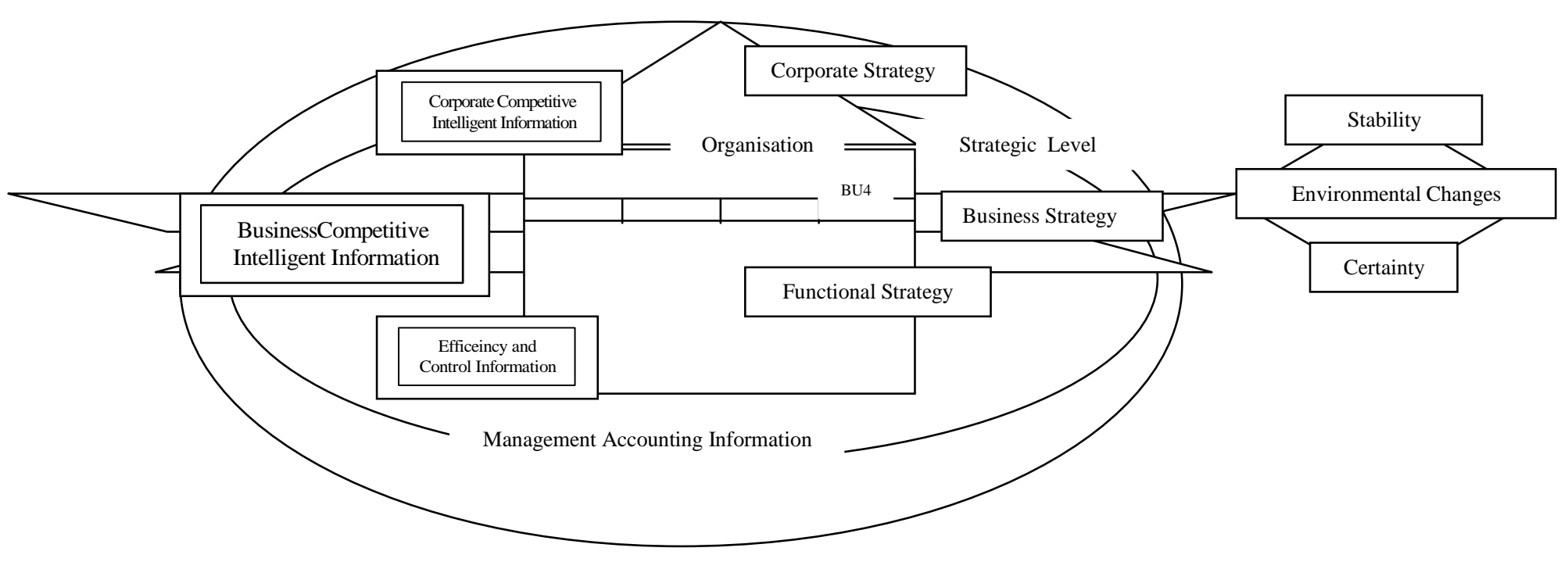


At functional level, both the objectives and directions (the policy and practice) are relatively clear and welldefined and limited to the actions of specific functions within a particular business. The clear link between objective and direction leads to specific goals and efficiency pressures for monitoring progress and, in turn, leading to adoptation of certain policies and routine practices of which $\mathrm{ABC}$ is an example.

At industrial level, pre-existence of clear objectives is problematic and strategies deal primarily with the question of competitive position. The implication is a confusion as to what will count as good strategic performance. As a result, firms adopt multiple strategies to achieve certain objectives, each with defined direction and certain practices in routine and on ad hoc basis to support the type and range of information they need.

At corporate level, specific objective is clear with multi-directions and practice which deal with the allocation of resources among various businesses or divisions of an enterprise. The strategic process is complex and concerns with a large number of variables related to the scope of an organization's activities and boundaries, and tends to be nonroutine in nature.

In practice, firms facing a high competition adopt multiple strategies to achieve certain objectives, each with specific direction and certain practices to support the type of information they need. Kohli and Jaworski (1990) confirm that the greater the competition the more a business must be market_oriented and must carefully assess the expected costs and benefits of pursuing its strategy of increased market orientation. The increased market orientation approach may hamper the performance and MAS information can assist firms in the identification, evaluation and implementation of appropriate strategies (Mia and Clarke, 1999).

To overcome the problem of understanding the contribution of management accounting to the complex process of strategic decision making, it is suggested that the relative significance of the use of management accounting information for efficiency purposes at functional and operational level is not related to environmental perceptions. But it is suggested that efficiency pressures (is) are limited to the actions of specific functions or operations within a particular business and rely essentially on the short-term of well-established budgetary control system. It is assumed that the use of cost information for such purposes is universal and will be addressed in future research as routine accounting. Corporate business strategy is the activity of choosing of what business and segment of the market the organisation is in and how to compete in each particular business and segment. Therefore, it is necessary to focus on where corporate resources will be invested whenever an organisation decides to expand its scope beyond a single product market and then, the chosen strategy must reflect in doing what the organisation is at its best as against competitors. Based on this premise, this study postulates two hypotheses in relation to the use of MAS information in shaping strategic choices of the firm in the light of the changing external environment .

\section{Linkage of certainty, managers' use of information and corporate strategy}

High degree of variablity in external environment from period to period makes forecasting and planning difficult. In uncertain environment, there is a premium for firms to respond to changing circumstances and alter the firm's overall orientation in order to manage the resource allocation, corporate portfolio and profitability. Under the conditions of increased uncertainty, managers increase the use of financial evaluation models and the amount of formal analysis (Cauwenbergh et al, 1996). Managers use a different strategy of uncertainty avoidance (increasing market concentration, securing distribution channels) to limit the impact of adverse environmental changes (Emmanuel et al, 1990). The major objective is to identify which business area the firm should be in.

Available literature postulates three alternative corporate strategic options: integration, diversification and strategic alliance (Hill and Jones, 2001). Achieving strategic alliance, in which firms' strategy and environment change, creates pressure on the firm's MAS to handle the new situations and to provide the required details.

The first hypothesis addresses the extent to which information is deemed to be relevant for corporate strategic decisions and is restated as follows:

$\mathbf{H}_{1}$ : As the perception of uncertainty increases, it is expected that managers would increase the use of corporate competitive analysis of different choices and alternatives to direct strategic options and legitimise their action. 


\section{Linkage of stability, managers' use of information and business strategy}

Literature on strategic management and competitive advantage postulates three strategic postures that firms may choose to compete in the same industry, namely, the overall cost-leadership differentiation (Porter, 1985); the defender-prospector (Miles and Snow, 1978); and the build-harvest strategic postures (Govindarajan and Shank, 1992). These strategic postures describe two strategic groups based on a simple strategy typology. On the one side, the strategy operates in a somewhat stable product area, offers more limited products than competitors and competes through costleadership style with little attention to product and market development; on the other side, the strategy operates in an unstable environment with changes over time, competes through new product and market development and seeks new market opportunities through product differentiation (Miles and Snow 1978; Porter 1985; Simons 1990; Govindarajan and Shank, 1992; Bruggeman and Van Der Stede, 1993; Lord, 1996).

Researchers in this area focus on how an accounting system can be designed most optimally in accordance with the specific strategy the firms have decided to follow in response to their external environment. Little attention is paid to the extent at which a management accounting practice would provide the strategic management information needed.

The general level of market conditions that makes earning profit difficult (market illiberality) appears to stimulate strategic movement and increases the demand on external strategic information and MAS may gather market intelligence information to support strategic development both on meeting competitive pressures and in strategic restructuring and reconfiguration of business strategy. The second hypothesis is restated as follow:

$\mathbf{H}_{2}$ : $\quad$ As the perception of illiberality increases, it is expected that managers would increase the use of business competitive analysis of different options and alternatives to direct choices and support strategic development.

To conduct this study two research variables are defined: company environment and cost practice use of cost information

\section{RESEARCH METHOD}

To test the hypotheses, a random sample of 110 large companies in the Eastern Province of Saudi Arabia was taken from the list of Saudi's 1000 largest companies. The survey was restricted to Eastern Province for accessibility reason. Initial contact was made with different senior executives including financial director, controller, senior accountant, internal auditor and managing director of each company to gain participation of the company and to arrange for the interview. Each senior executive was interviewed using a structured questionnaire. The answers were solicited from different senior executives familiar with management accounting policies and practice at their companies as well as the market in which their companies were operating.

Ninety companies showed their interest to participate in the study, of which sixty-five companies participated in the intervew and completed the questionnaire. Twenty-five of the ninety companies apologized for not being able to participate due to extreme pressures of work at the time when the study was conducted. Eleven questionnaires had some incomplete sections and were excluded from the study. Thus, the response rate is 49 per cent leading to 54 usable questionnaires.

The remaining 20 companies had different reasons for not participating in this research project. They included, inter alia, heavy workload, a policy to decline participation in surveys, extreme pressures of work at this point of time, sensitive nature of the issues raised, the length of the questionnaire and lack of interest in the topic.

\section{Company Environment}

Buchko (1994) provided an overview of the literature in this area. He found that researchers relied primarily on three scales. The first was developed by Lawrence and Lorsch (1967) which examined the uncertainty associated with a specific job or function. This measure was criticised to be not appropriate for the assessment of an organisation's general environment (Milliken 1987). The second scale was developed by Duncan (1972) which was based on two dimensions: 
complexity and dynamism. This scale was reported to be (1) not consistent (Downey et al, 1975), ranging from predictability through dynamism and complexity, and (2) not conceived as a strategic construct (Tymon et $a l, 1998)$. The third scale was developed by Miles and Snow (1978). They defined the perceived environment uncertainty in terms of unpredictability. The scale contains 25 items, with six subscales containing 2 to 6 items each. Researchers suggested that this scale may be a more appropriate measure for environmental conditions than its alternatives (Hambrick 1983, Milliken 1987, and Buchko 1994). Further, this scale proved to be consistent and reliable (Tosi and Slocum 1984, Buchko 1994).

Ibbotson (1974) constructed a scale based on two dimensions related to illiberality and unpredictability to measure organisations' perceptions on environmental conditions. He had indicated that managers found it difficult to locate their companies on the provided scales if they were given only the general definition of the concepts of illiberality and unpredictability. This is because the concepts of illiberality = "the extent to which the markets, etc, were perceived to be competitive", and unpredictability z"the extent to which environment was perceived as predictable", were defined as (a) strong negatives; to make the scaling easy, Ibboston adopted two extreme points for each environmental sector. Each point described in words a typical environmental condition facing companies.

Based on Ibbotson's study (1974) and other relevant literature (Lawrence and Lorsch, 1967; Duncan 1972; Khandwalla 1972; Ibbotson, 1974; Downey et al, 1975; Miles and Snow, 1978; Snow and Hrebiniak, 1980; Miller and Friesen, 1982; Hambrick, 1983; Dess and Davis, 1984; Tosi and Slocum, 1984; Milliken 1987, and Buchko 1994), Alhazmi (1995) constructed a multi-item scale for measuring organisations' perceptions of environmental conditions. The multi-item scale contained 42 items relating to three main environmental sectors: (1) product market, (2) factor market and (3) legislation. The respondents were asked to assess the various sectors of their firms' environment on dimensions of illiberality and unpredictability ranging from low to high degree using a five-point scale for each dimension. In addition, the respondents were asked to rank the sectors in order of their relative importance, and to allot percentage weights to each sector. He found that firstly, the perception of illiberality and unpredictability may be less likely to be a response of a single score, but a response of separate scores for different sectors which can not be added up to give single index to measure overall perceived environmental illiberality. Secondly, companies appear to differntiate between illiberality and unpredictability of individual sectors but they tend to have similar scores at aggregate level. A conventional t-test $($ at $\mathrm{p}<0.05$ ) of illiberality yielded no significant differences between the overall calculated mean (3.08) and overall assessment of illiberality index (3.35). A further correlation analysis was performed which showed high correlation (0.732) between the two means at 0.001 level of significance. This, of course, justified the use of both measures of illiberality to indicate overall index. Thirdly, managers appear to differntiate between the relative importance of illiberality and unpredictability for both the product market and the overall situation. Finally, it appears that companies paid a considerable attention to product market sector. Hence, it was decided to use the six-item scale of product market as a strategic construct to measure the perceived illiberality and unpredictabilty ${ }^{1}$. However, it was found that the respondents might have some concern regarding the constituted meaning of both illiberality and unpredicatabilty and in this case they were changed to instability and uncertainty. This cofusion may be partly contributed to differences in cultural and social constitute.

This study shows that the coefficients of alpha for the perceived environmental instability and uncertainty are 0.72 and 0.71 respectively. The overall measures are reasonably positive and indicate high levels of internal consistency (Nunnally 1978; Gibbon and Morris 1987).

\section{Cost Practices}

A major strand of management accounting research focused on examining the relationship between certain aspects of contextual variables, (e.g. organisation' perception of environment), management accounting system (MAS) information characteristics and performance (Khandwalla, 1972; Dew and Gee, 1973; Gordon and Miller, 1976; Scapens et al, 1982; Gordon and Narayanan, 1984; Chenhall \& Morris, 1986; Howel et al., 1987; Lyne, 1987; Ansari and Euske, 1987; Simon, 1987/90; Mia and Chenhall, 1994; Gul and Chia, 1994).

1 Tymon, Stuot and Saw (1998) conceived the PEC as a strategic level variable pertaining to top management's perceptions of uncertainties in the external environment. 
Chenhall and Morris (1986) developed an instrument to measure the percieved usefulness of MAS information characteristics using four dimensions of information characteristics. This measurement construct was adopted and used widely by other researchers (Mia Chenhall, 1994; Chia, 1994). Mia and Chenhall (1994) adopted the instrument of Chenhall and Morris (1986). They asked managers to indicate, on a five/seven point Likert scale, the extent to which they used six items of information provided by their organisation's MAS.

Based on these studies, field work outcomes and other relevant literature (Khandwalla, 1972; Dew and Gee, 1973; Ibbotson, 1974; Berry, 1976; Scapens, 1982; Howel et al., 1987; Bourn and Ezzamel, 1987; Lyne, 1987; Ansari and Euske, 1987; Ramadan, 1989, Innes and Mitchel, 1990; Simon, 1987/90; Bright et al., 1992; Hoque, 1993), Alhazmi (1995) developed the measurement construct for cost practices in relation to time: short, medium and long-term. The objective was to measure the extent of use of cost information in relation to three themes: (1) uses for system maintenance and efficiency; (2) uses for system optimization; and (3) uses for system adaptation.

The scale adopted detailed attributes for each of the three types of the uses of cost information based on 46-item scale which described possible uses of cost information. A five-point Likert scale (ranging from 1=extremely important to 5=not important) was used to express the respondent's view regarding the significance of cost information uses at his company. It was decided to use the 14-item scale for system adaptation in order to gain insight into cost practices, in this case the use of cost information for strategic consideration.

To portray the relation among the variables, a factor analysis was performed. Variables included as part of each factor had a of 0.5 or higher. The 14-item data set produced two factors, namely: (1) corporate competitive intelligent information and (2) business competitive intelligent information. As shown in Table 1, factor analysis showed high degree of stability in the costruct with coefficient alpha scores ranging from 0.9234 to 0.9553 . In addition to this, KMO measure and Bartlett's tests were high and significant which suggested that the data were appropriate for factor analysis (Kaiser and Rice1974; Cerny and Kaiser, 1977; Bobko, 1995)

Table 1: Factor Anylysis and Reliability

\begin{tabular}{|l|c|c|c|}
\hline \multirow{2}{*}{ Orthogonally rotated solution of the total variance } & \multicolumn{3}{|c|}{ Cost practices profile for cost information uses } \\
\cline { 2 - 4 } & Uses of cost information for system adaptation \\
\cline { 2 - 4 } & Corporate Intelligent & Business Intelligent & Overall \\
\hline KMO measure of sampling adequacy & 36.950 & 34.669 & 73.619 \\
\hline Bartlett's test of sephericity & NA & NA & 0.755 \\
\hline Reliability coefficient of internal consistency (Alpha) & NA & NA & $508.148(\mathrm{p}<.000)$ \\
\hline
\end{tabular}

\section{FINDINGS AND DISCUSSION}

An exploration of the results of the relationship of the uses of cost information in relation to product market instability and uncertainty is shown in Table 2 .

As shown in Table 2, the evidence suggests the following:

\section{Perceived Instability and Uncertainty}

This study offers a variable construct for assessing company environment. The construct is a six-item scale of product market used as strategic construct which relates managers' perceptions on the two dimensions of their enviroment.

The managers appear to differntiate their perceptions between the relative importance of environmental instability and uncertainty with the lowest significance being given to unpredictability (2.8515). These two types have been summed up under the umbrella of PEU in previous studies (Gordon and Narayanan, 1984,; Chenhall and Morris, 1986; Otley, 1987; Mia, 1993; Tymon et. al, 1998; Mia and Clarke, 1999). These studies considered market competition as a factor in environmental and reported that (1) the usefulness of management accounting information 
systems increases with the increased environmental uncertainty, (2) the major underlying factor affecting accounting information system design is environmental unpredictabilty (uncertainty) which indicates the overall degree of variability from period to period that makes forecasting and planning difficult.

Table 2:Existence of Correlation between

Perceived Environment Conditions and Uses of Cost Information for Strategic Choices

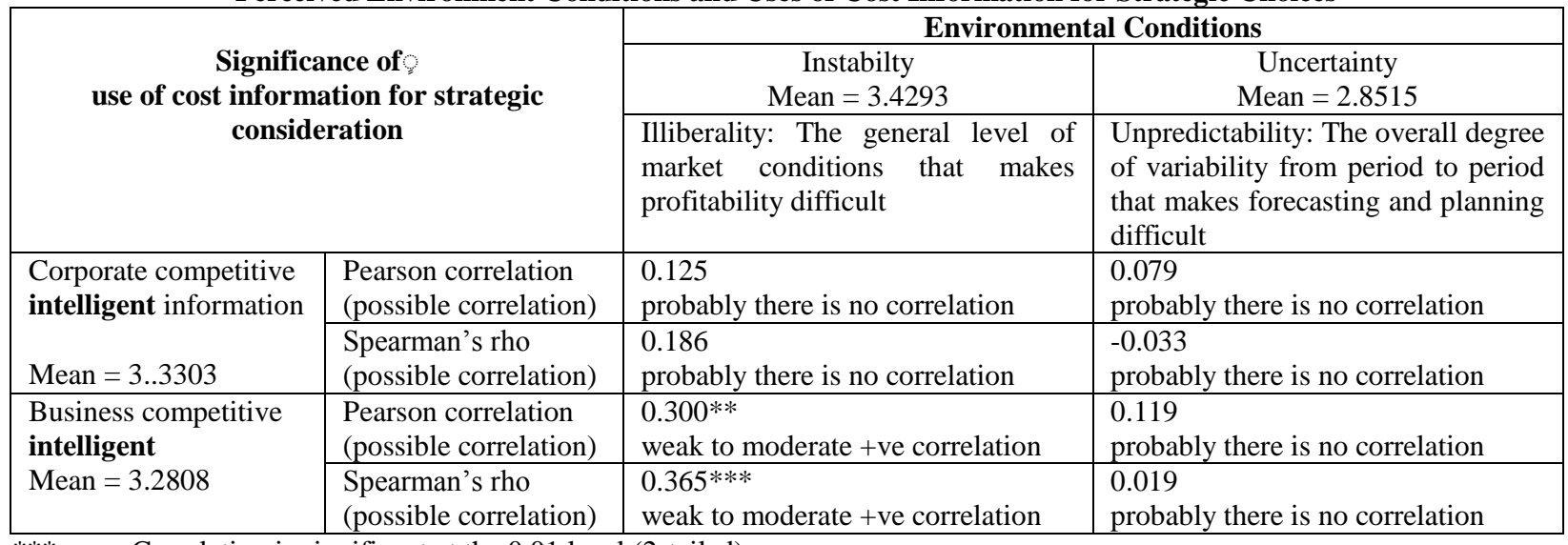

*** Correlation is significant at the 0.01 level (2-tailed).

** Correlation is significant at the 0.05 level (2-tailed).

* Correlation is significant at the 0.10 level (2-tailed).

This study diverges from accounting perceived environmental uncertainty (PEU) in behavioural accounting research in two ways. Firstly, the measurement construct establishes PEU as a strategic construct where it refers to (1) external environment of an organization; (2) perceptions of that environment; (3) the degree of turbulent results from the perceptions, and (4) the relevant perceptions of top management (Tymon et al, 1998).

Secondly, the measurment construct relates to managers' perceptions of two dimensions of their environment. This study adds a second dimension of environmental illiberality and is used to indicate the general level of market conditions that adversly affect profitability. A conventional t-test suggests that there is a significant difference between the two means of the perceived instability and uncertainty in product market at $\mathrm{p}<0.01$. A further correlation analysis at 0.05 level of significance is performed which shows that the means of instability and uncertainty are not correlated with each other.

\section{Managers' use of management accounting information and strategic choices}

This study offers a variable construct with high level of internal consistency for assessing managers' use of MAS for strategic choices.

Managers appear to differentiate between two types of management accounting information: corporate competitive intellegent information (3.3303) and business competitive intelligent information (3.2808). A conventional t-test suggests that there is no significant difference between the two means at $\mathrm{p}<0.05$. Correlation analysis performed shows strong positive correlation $(0.710)$ between the two means at $\mathrm{p}<0.01$.

This observation raises questions regarding: whether (1) the formal MAS provides the strategic management information needed, (2) the relevance and quality of formal analysis depend on the way the decision and associated analysis is structured (Shank, 1996), and (3) whether the use of information is coupled with the view that strategies tend to be incremental in nature (Mintzberg, 1978) and a wider range of informal strategic information is linked with ad hoc management accounting practice to provide the details needed. 
A t-test has been conducted to test whether there are differences in the relative significance of the uses of management accounting information at corporate or business level between those reported having strategic cost management policy and those without.

Firstly, as shown in Table 3, companies without strategic cost management policy accord higher significance to the use of management accounting information for corporate competitive intelligence (3.9032) and the difference between the two means is significant at $p<0.05$. This evidence of the relationship between policy and practice acknowledges the use of management accounting information as a practice for strategic choice. However, it is not clear how the use of management accounting information is interwoven with the strategic process or whether the way the information used promotes the goals of an organization. It seems that other managerial focus might be a prior explanation of both strategic choices and the use of management accounting information to support strategic development information in line with their intuitions and understandings (Simons, 1990).

Table 3:T-Test for the Equality of Means at $\mathbf{p}<0.05$

Existence of Strategic Cost Management Policy and Uses of Cost Information for StrategicChoices

\begin{tabular}{|l|c|c|c|}
\hline \multicolumn{1}{|c|}{$\begin{array}{c}\text { Significance of use of cost information for strategic } \\
\text { consideration }\end{array}$} & \multicolumn{2}{|c|}{ Existence of Strategic Cost Management Policy } \\
\cline { 2 - 4 } & Yes & No & 0.003 \\
\hline $\begin{array}{l}\text { Corporate Competitive Intellegent Information } \\
\text { Mean = 3.3303 }\end{array}$ & 3.0252 & 3.9032 & 0.067 \\
\hline $\begin{array}{l}\text { Business Competitive Itellegent Information } \\
\text { Mean = 3.2808 }\end{array}$ & 3.0445 & 3.5651 & Significance level \\
\hline
\end{tabular}

Secondly, companies with strategic cost management policy accord higher significance to the use of management accounting information for business competitive intelligence (3.0445) and the difference between the two means is not significant at $\mathrm{p}<0.05$. This observation suggests that the use of management accounting information in relation to strategic choices exists and MAS information is brought into use where there is a need for strategic behavior driven by market position, logistic arrangement, market share, conversion cost and capacity pressures.

\section{Uncertainty and corporate strategy}

The relative significance of the use of management accounting information for corporate competitive intelligence has not been found to be not associated with instability and uncertainty which suggestes that the use of management accounting information for such purposes is a common practice. However, when the sample is split on the basis of existence of cost policy as shown in Table 3, it is apparent that, for those companies reported having strategic cost management policy, the relative importance of the use of management accounting information is the lowest (3.0252). ). A conventional t-test suggests that there is a significant difference between the two means at $\mathrm{p}<0.01$.

This evidence raises three questions regarding the extent to which MAS information is deemed to be relevant for corporate strategic decisions.

Firstly, does the model of management accounting pay attention to the accounting process where the meaning of cost structure in future time periods appears to be related to the constraints of fixed and variable cost in relation to volume and capacity, and to the likelihood of there being a declining cost level as production cumulates from period to period? Secondly, how does MAS contribute to the complex process of decision making where cost structure could be an outcome of strategic choices as well as an input into strategy? (Dent, 1990). Thirdly, what is the extent of formal and informal analysis (Cauwenburgh et al,1996) and the quality and depth of strategic analysis conducted (Shank, 1992).

It seems that: (1) the practice of the firms is to use management accounting information for strategic purposes and the management accounting practice entered markedly into the strategic process as a financial model and as a cost model for evaluation and is part of the pattern company activities, (2) there is a lack of formalized data 
gathering and little relationship between the level of environmental turbulence and the amount and the kind of external information firms gathered, and (3) MAS is an important tool of strategic management though the formal information gathering is limited on providing external information and tends to ignore non-accounting and non-economic information. The lack of formalized data gathering may lead managers to use informal and ad hoc collection of strategic management information and search for a continuous adaptation to maintain strategic alignment (Slagmulder, 1998).

\section{Instability and business strategy}

The relative significance of the use of cost information for business competitive intellegence is found to be not associated with uncertainty but positively correlated with instability. The responses suggest that a relationship exists which is significant. However, when the sample is split on the basis of existence of cost policy as shown in Table 3, it is apparent that, for those companies reported having strategic cost management policy, the relative importance of the use of cost information is the lowest (3.0445). ). A conventional t-test suggests that there is a significant difference between the two means at $\mathrm{p}<0.10$.

An interpretation of this result is that though there is no formal strategic cost management policy, market illiberality stimulates strategic movement and management accounting information is being used in management thinking to support strategic development in meeting competitive pressures and in restructuring and reconfiguration of business strategy.

This evidence provides supports for our hypotheses that the managers use of MAS information in relation to business strategy exists and is related to the perception of illiberality. This offers an empirical support for Bromwich's (1990) theoretical argument that firms operating in a competitive environment can benefit from using information for decision making.

These led us to ask how and when do managers interface with MAS? A processable model with longitudinal case study might offer new avenues for developing the research and give some attention to the question of time and connectedness of actions. This simple managerialist mode incorporates the significance of human choices and action and might link into the ideas of Simmonds (1981), Bromwich (1990) and Dent (1990). Future studies will benefit from looking into these issues.

\section{CONCLUSION}

This study postulates two hypotheses in relation to the use of MAS information in shaping strategic choices of the firm in the light of the changing external environment. The study offers two constructs which relate managers' perceptions of two dimensions of their environment (instability and uncertainty) to the managers' use of MAS information in shaping strategic choices at two levels of relative significance accorded to competitive intelligent information. The study also extends previous research by incorporating a second dimension of instability into the analysis of external environment.

The results show that (1) managers' perception on environmental instability and uncertainty differs; (2) the relative significance accorded to business competitive intelligent information is positively associated with rising instabilty(:) and (3) corporate competitive intelligent information is common. An interpretation of the results is that market instabilty appears to stimulate strategic movement and cost information is being used in management thinking to support strategic development on both meeting competitive pressures and in strategic restructuring and reconfiguration of business strategy.

The establishment of the two hypotheses is criticised on the grounds that the correlations are small and may lead to insignificant or inconclusive findings (Child, 1972, 1973; Wood, 1979; Schreyogg, 1980; Cooper, 1981; Govindarajan and Gupta, 1985; Merchant, 1985; Otley, 1985, 1989; Dunk, 1989; Briers \& Hirst, 1990; Hoque, 1993). However, the study provides useful insights for understanding how the managers use of MAS information is linked to the strategic choices of the firm in the light of changing external environment. 


\section{ACKNOWLEDGEMENT}

The author would like to gratefully acknowledge the excellent research facilities and other support provided by King Fahd University of Petroleum \& Minerals, Dhahran, Saudi Arabia, to carry out this work.

\section{AUTHOR INFORMATION}

Dr. Muhammad Al-Hazmi is a faculty member at the department of accounting and MIS (KFUPM). He is involved in teaching courses at graduate, undergraduate, diploma and professionsl levels. Currently he is the chairman fo the accounting department and serves as a member of Tax and Appeal Committee appointed by the Ministey of Finance and a member of Consulting Services Committee appointed by Saudi Organization for Certified Public Accountants. His research interest includes financial and manaerial accounting, zakat and taxation. Dr. AlHazmi consulted several government and private organizations.

\section{REFERENCES}

1. Al-Hazmi, M. H. (1995) Cost Policies and Cost Practices in UK Manufacturing Industry. Unpublished PhD Thesis, University of Manchester, Manchester Business School.

2. $\quad$ Al-Hazmi, M. H. and Berry, A.J. (1994) "Cost Policies and Practices", Paper presented at the Management Accountin Research Group Conference, Aston Business School, 8-9 September 1994, An earlier version of this paper was presented at the British Accounting Association Conference at Winchester, March 1994.

3. Ansoff, H. I and Sullivan, P A. (1993) "Optimizing Profitability in Turbulant Environments: A Formula for Strategic Success", Long Range Planning, London,Vol. 26, No. 5, 11-24.

4. Berry, A. J. (1976) Control of Capital Investment in Large Enterprise. Unpublished PhD Thesis, University of Manchester, Manchester Business School.

5. Bobko, P. (1995) Correlation and Regression: Principles and Applications for Industrial/Organizational Psychology and Management. McGraw-Hill, INC.

6. $\quad$ Bourn, M. and Ezzamel, M. (1987) "Why Firms Allocate Costs ?", in R. Scapens, J. Arnold and D. Cooper (eds), Management Accounting: British Case Studies, London: CIMA, pp. 315-350.

7. Briers, M. and Hist, M. (1990) "The Role of Budgetary Information in Performance Evaluation", Accounting, Organisations and Society, Vol. 15, No. 4, pp. 373-398.

8. Bright, J., Davies,R., Downes, C. and Sweeting, R. (1992) "The Deployment of Costing Techniques and Practices : A UK Study", Management Accounting Research, 3, pp. 201-212.

9. Bromwich, M. (1990) "The Case for Strategic Management Accounting: The Role of Accounting Information for Strategy in Competitive Markets", Accounting, Organisation and Society, Vol.15, No.1/2. pp. 27-46.

10. Brouthers, K. D. and Roozan, F. A. (1999) "Is It Time to Start Thinking about Strategic Accounting", Long Range Planning, London, Vol. 32, No. 3, 311-322.

11. Bruggeman, W. and Van Der Stede, W. (1993) "Fitting Management Control Systems to Competitive Advantage", British Journal of Management, pp. 205-218.

12. Buchko, A.A. (1994) "Conceptualization and Measurement of Environmental Uncertainty: An Assesment of Miles and Snow Perceived Environmental Uncertainty Scale", Academy of Management Journal, Vol. 37, No. 2, pp. 410-425.

13. Cauwenbergh, A. V., Durinck, E., Martens, R., Laveren, E. and Bogaert, I. (1996) "On the Role and Function of Formal Analysis in Strategic Investment Decision Processses: Results from an Empirical Study in Belgium", Management Accounting Research, 7, 169-184. Academic Press Limited.

14. Cerny, B. A. and Kaiser, H. F. (1977) "A Study of a Measure of Sampling Adequacy for Factor-Analytic Correlation Matrices" Multivariate Behavioural research, 12, 43-47.

15. Child, J. (1972) "Organization Structure, Environment \& Performance", Sociology, Vol. 6, No. 1, pp.1-22;

16. Child, J. (1973) "Predicting and Understanding Organisation Structure", Administrative Science Quarterly, Vol. 18, No. 2, pp. 168-185.

17. Cooper, R. and Slogmulder, R (1998) "Strategic Cost Managemnt", Management Accounting, January.

18. Cooper, D.J. (1981) "A Social and Organisational View of Management Accounting", in Bromwich, M. and Hopwood, A.G. (eds), Essays in British Accounting Research, London: Pitman. 
19. Dent, J. (1990) "Strategy, Organisation and Control: Some Possibilities for further Accounting Research", Accounting, Organisation and Society, Vol. 15, No. 1/2, pp. 3-25.

20. Dess, G.S and Davis, P.S. (1984) "Porter's (1980's) Generic Strategies As Determinants of Strategic Groups Membership and Organisational Performance", Academy of Mamagement Journal, Vol. 27, No. 3, pp. 467-488.

21. Downey, H.K., Hellriegel, D. and Slocum, J.W. (1975) "Environmental Uncertainty: The Construct and Its Application", Administrative Science Quarterly, pp. 613-629.

22. Downey, H. and Slocum, J. (1975) "Uncertainty: Measures, Research \& Sources Of variation", Academy Of Management Journal,pp.562-77.

23. Duncan, R.B. (September 1972) "Characteristics of Organisational Environments and Perceived Environmental Uncertainty", Administrative Science Quarterly, pp. 313-327.

24. Dunk, A.S. (1989) "Budget Emphasis, Budgetary Participation and Managerial Performance: A Note", Accounting, Organisations and Society, vol. 14, No. 4, pp. 321-324

25. Emmanuel, C., Otley, D. and Merchant, K. (1990) Accounting for Management Control, $2^{\text {nd }}$ ed, Chapman and Hall.

26. Gibbon, C.T. and Morris, L.L. (1987) How To Analyse Data, Cal.: Sage Publications.

27. Gordon, L.A. and Miller, D.A. (1976) "A Contingency Framework for the design of Accounting Information System", Accounting, Organisations and Society, Vol. 1, pp. 59-69.

28. Gordon, L.A. and Narayanan, V.K. (1984) "Management Accounting Systems, Perceived Environmental Uncertainty and Organisation Structure: An Empirical Investigation", Accounting, Organisations and Society, vol. 9, No. 1, pp. 33-47.

29. Govindarajan, V. and Gupta, A.K. (1985) "Linking Control Systems in Business Unit Strategy", Accounting, Organisation and Society, Vol. 10.

30. Govindarajan, V. and Shank, J.K. (1992) "Strategic Cost Management: Tailoring Controls to Strategies", Journal of Cost Management, Vol. 6, No. 3, pp. 14-26.

31. Gul, F.A. and Chia, Y.M. (1994) "The Effects of Management Accounting Systems, Perceived Environmental Uncertainty and Decentralisation on Managerial Performance: A Test of Three-way Interaction", Accounting, Organisations and Society, Vol. 19, No. 4/5, pp. 413-426.

32. Hambrick, D.C. (1983) "Some Tests of the Effectivenessand Functional Attributes of Miles and snow's Strategic Types", Academy of Management Journal, pp. 5-26.

33. Harrison, E.F. (1987) The Managerial Decision-Making Process, 3rd edn, Boston, Houghyon Miffin Co.

34. Hill, C. W. and Jones, R. G. (2001) Strategic Management: An Integrated Approach, $5^{\text {th }}$ ed, Houghton Mifflin Company.

35. Hofer, C.W. and Schendel, D.E. (1978) Strategy Formulation: Analytical Concepts, New York: West.

36. Hoque, Z. (1993) Management Control in Public Sector Enterprises: A Case Study of Budgeting in the Jute Industry of Bangladesh, Unpublished PhD Thesis, University of Manchester.

37. Howell, R., Brown, J., Soucy, S. and Seed, A. (1987) Management Accounting in the New Manufacturing Environment, National Association of Accountants.

38. Ibbotson, G.I. (1974) "Capital Investment as a Strategic Response in the Corporate Environment". Unpublished PhD Thesis, Univesity of Manchester.

39. Innes, J. and Mitchell, F. (1990) "The Process of Change In Management Accounting", Management Accounting Research, pp. 3-19.

40. Innes, J. and Mitchell, F. (1990) Activity Based Costing: A Review with Case Studies, CIMA, Unwin Brothers Ltd.

41. Johnson, G. and Scholes, K. (1993) Exploring Corporate Strategy, Hemel Hempstead: Prentice-Hall.

42. Kaiser, H. F. and Rice, J. (1974) "Little Jiffy, Mark IV", Education and Psychological Measurement, 34, 111-117.

43. Kasurinen, T. (2002) "Exploring Management Accounting Change: The Case of Balanced Scorecard Implementation”, Management Accounting Research, 13, 323-343. . Academic Press Limited.

44. Khandwalla, P.N. (1972) "The Effect of Different Types of Competition on the Use of Management Control", Journal of Accounting Research, vol. 10, pp. 275-285.

45. Kohli, A. J. and Jaworski, B. J. (1990) "Market Orientation: the Construct, Research Propositions, and Managerial Implications. Journal of Marketing, 1-8.

46. Lawrence, P. and Lorsch, J. (1967) Organization and Environment, Ma:Harvard University Press. 
47. Lord, B. R. (1996) "Strategic Management Accounting: the Emperor's New Clothes”, Management Accounting Research, 7, 347-366. Academic Press Limited.

48. Lyne, S. (1987) "The Role and Perception of Company Budgets", in Arnold, J., Scapens, R. and Cooper, D. (eds), Management Accounting: Exploring the Horisons, Vol. 3, London: CIMA, pp. 309-368.

49. Management Accounting Research, A Special Issue of MAR on Strategic Management Accounting. 1996. Academic Press Limited.

50. Merchant, K. (1985) Control in Business Organisations, London: Pitman.

51. Mia, L. and Clarke, B. (1999) "Market Competition, Management Accounting Systems and Business Unit Performance", Management Accounting Research, 10, 137-158. Academic Press Limited.

52. Mia, L. and Chenhall, R.H. (1994) "The Usefulness of Management Accounting Systems, Functional Differentiation and Managerial Effectiveness", Accounting, Organisations and Society, Vol. 19, No. 1, pp. 113.

53. Miles, R.E. and Snow, C.C. (1978) Organisational Strategy, Structure and Process, New York: McGraw Hill.

54. Miller, D. and Friesen, P.H. (1982) "Innovation in Conservative and Entrepreneurial Firms, Strategic Management Journal, pp. 1-27.

55. Milliken, F.J. (1987) "Three Types of Perceived Uncertainty about the Environment", Academy of Management Review, Vol. 12, pp. 133-143.

56. Mintzberg, H. (1978) "Patterns in Strategy Formation", Management Science, pp. 934-948.

57. Nixon, B. and Alasadair Lonie, A (1992) "Technological Innovation and Management Accounting Control: Some Evidence From 13 Case Studies", Paper Presented at the 2nd Workshop on Accounting, Strategy and Control, Brussels, Begium.

58. Nunnally, J.C. (1978) Psychometric Theory, 2nd Ed., New York: MaGraw-Hill.

59. Otley, D. (1989) "A Strategy for the Development of Theories in Management Control", in Chua, W.F., Lowe, T. and Puxty, T. (eds), Critical Prspectives in Management Control, London: MacMillan.

60. Porter, M.E. (1985) Competitive Advantage: Creating and Sustaining Superior Performance, New york: The Free Press.

61. Quinn, J.B. (1980) Strategy for Change: Logical Incrementalism. Homewood III, Irwin.

62. Ramadan, S. (1989) "The Rationale for Cost Allocation: a Study of UK Divisionalised Companies", Accounting and Business Research, Vol. 20, No. 77, pp. 31-37.

63. Scapens, R.W., Sale, J.T. and Tikkas, P.A. (1982) Financial Control of Divisional Capital Investment, ICMA.

64. Schreyogg, G. (1980) "Contingency and Choice in Organisation Theory, Organisation Studies, Vol. 1, pp. 8187.

65. Shank, J. K. (1996) “Analysing Technology Investments: from NPV to Strategic Cost Management”, Management Accounting Research, 7, 163-280. Academic Press Limited.

66. Shank, J.K. (1989) "Strategic Cost Management: New Wine or Just New Bottles", Journal of Management Accounting Research, Fall, pp.47-65.

67. Shank, J.K. and Govindarajan, V. (1989) Strategic Cost Analysis: The Evolution from Managerial to Strategic Accounting, Homewood II, Irwin.

68. Simmonds, K. (1981) "Strategic Management Accounting", Management Accounting, Vol. 59, No. 4, pp. 2629.

69. Simons, R. (1987) "Accounting Control and Business Strategy", Accounting, Organisations and Society, pp. 357-374.

70. Simons, R. (1990) "The Role of Management Control Systems in Creation of Competitive Advantage", Accounting, Organisation and Society, Vol. 15, No. 1/2, pp. 127-143.

71. Slagmulder, R, (1997) “Using management Accounting Control Systems to Achieve Alignment between Strategic Investment decisions and Strategy”, Management Accounting Research, 8, 103-139. Academic Press Limited.

72. Snow, C.C. and Hambrick, D.C. (1980) "Measuring Organisation Strategies: Some Theoretical and Methodological Problems", Academy of Management Review, pp. 527-538.

73. Snow, C.C. and Hrebiniak, L.G. (1980) "Strategy, Distinctive Competence, and Organisation Performance", Administrative Science Quartly, Vol. 25, pp. 317-336.

74. Tosi, H. and Slocum, T.W. (1984) "Contingency Theory: Some Suggested Directions", Journal of Management, Vol. 10, pp. 9-26. 
75. Tymon, W. G., Stout, J. D. and Shaw, K. N. (1998) "Critical Analysis and Recommendations Regarding the Role of Perceived Environmental Uncertainty in Behavioral Accounting Research", Behavioral Research in Accounting, Vol. 10, pp 23-46.

76. Wilson, R. (1991) "Strategic Management Accounting", in D. Ashton, T. Hopper and R. Scapens, Issues in Management Accounting, Prentice Hall, pp. 82-105.

77. Wood, S. (October 1979) "Reappraisal Of The Contingency Approach To organization", Journal Of Management Studies, pp. 334-354.

\section{NOTES}

